\title{
Effect of Butyric Acid Supplementation on Gut Health in Broiler Chicken
}

\author{
D. Nataraja ${ }^{1 *}$, V. Malathi ${ }^{1}$, J. N. Sreedhara ${ }^{1}$, Jayanaik ${ }^{1}$ and B. Kavitha Rani ${ }^{2}$ \\ ${ }^{1}$ Department of Poultry Science, Veterinary College, Hebbal, Bengaluru- 560024, India \\ ${ }^{2}$ Department of Veterinary Pathology, Veterinary College, Shivamogga, \\ Karnataka Veterinary, Animal and Fisheries Sciences University, Karnataka, India \\ *Corresponding author
}

\section{A B S T R A C T}

\begin{tabular}{|l|}
\hline Ke y w o r d s \\
Gut health, E. coli, \\
Duodenum, Goblet \\
cells, Gut $\mathrm{pH}$
\end{tabular}

\begin{abstract}
An experiment was conducted using 600 broiler chicks to investigate the effect of four levels of butyric acid $(0,0.1,0.2$ and $0.4 \%)$ on gut health from day 1 to 42 days. Influence of butyric acid on $\mathrm{pH}$ in different sections of the small intestine, gut histomorphology and the microbial load in the caecum was tested on 21 days and 42 days of the trial. Gut $\mathrm{pH}$ was significantly higher in duodenum and ileum on day 21 and only duodenum on day 42 . Caecal E. coli, Salmonella spp. and Clostridium spp. count was significantly lower and Lactobacilli spp. count was significantly higher in butyric acid supplemented groups. Intestinal villous height was significantly higher in duodenum, jejunum on day 21 and duodenum, jejunum and ileum on day 42, intestinal crypt depth was significantly higher in all sections of small intestine except in ileum on day 42 in BA supplemented groups. Except in ileum on day 21, the goblet cell count was significantly higher in all sections of the small intestine in treated groups.
\end{abstract}

\section{Introduction}

Antibiotics have been used as growth promoters in poultry to improve performance by reducing the burden of pathogens (Dibner and Richards, 2005). Currently, there is a restriction on the use of antibiotic growth promoters (AGPs), for the reason of developing antibiotic resistance (Naveen kumar et al., 2018). Butyric acid (BA) is one of the important organic acids that can be used as alternative to antibiotics (Leeson et al., 2005). Butyric acid being a SCFA, has higher bactericidal activity when the acid is undissociated (Leeson, 2007). Bacterial cell take up undissociated fatty acids and once these acids dissociate, there is change in the intracellular $\mathrm{pH}$ leading to death of bacterial cells. Supplementation of butyric acid derivatives in the diets of broiler chickens could replace antibiotics while maintaining growth performance (Namkung et al., 2011), decrease infection by Salmonella enteritidis (Fernandez-Rubio et al., 2009), and increase growth performance under stress (Zhang et al., 2011). Researchers have observed that butyrate is quickly absorbed in the upper digestive tract, mainly the crop, which makes it less ideal as a feed additive. They have also observed that butyrate is necessary for normal 
epithelial cell development; therefore, if the butyrate could bypass degradation in the crop and proven triculus, then the epithelial cells in the small intestine could utilize the butyrate. Butyric acid is a readily available energy source for intestinal villi and stimulates their differentiation and multiplication, consequently increases feed efficiency (Adil et al., 2011). It also induces the production of host defense peptides when it enters bloodstream. Villi height and absorptive surface of the small intestine increases leading to better nutrient utilization (Smulikowska et al., 2006; $\mathrm{Hu}$ and Guo, 2007; Czerwi’nski et al., 2012).

A balanced gut microbiota constitutes an efficient barrier against pathogen colonization, produces metabolic substrates such as vitamins and short-chain fatty acids, and stimulates the immune system in a noninflammatory manner. Butyric acid may also reduce hindgut protein fermentation because it suppresses protein-fermenting microbiota, especially the gram-negative population in broilers (Gunal et al., 2006), by disrupting their energy metabolism (Ricke, 2003) and decreasing hindgut $\mathrm{pH}$. In addition, butyric acid decreases bacterial colonization of the intestinal wall (Langhout et al., 1999) and as a consequence, less toxic compounds are produced by pathogenic microbiota, resulting in less damage to the epithelial cells (Antongiovanni et al., 2007). In this context, the present study was conducted to evaluate potential benefits of butyric acid on the gut health of broilers.

\section{Materials and Methods}

\section{Dietary treatments and management}

A total of Six hundred, day old straight run commercial broiler chicks were randomly divided into four treatment groups, each treatment consisted of six replicates of twenty five chicks each. Broilers were fed with diets as per NRC (1994) specifications (Table 1). Birds were fed with basal diet along with graded levels of $(0.1,0.2$ and $0.4 \%)$ butyric acid. Chicks were reared under deep litter system with all standard managemental practices till six weeks of age and standard vaccination schedule was followed for immunizing chicks. Feed and water was provided ad libitum.All the procedures followed during the trial were approved by the Institutional animal ethical committee, Veterinary College, Bengaluru, KVAFSU, Bidar.

\section{Gut health}

On $21^{\text {st }}$ and $42^{\text {nd }}$ day of the experiment, 12 birds from each treatment group were sacrificed and intestinal content from duodenum, jejunum and ileum was collected for $\mathrm{pH}$ estimation. The caecal contents were collected aseptically in sterile container and immediately subjected to enumeration of gut microbes viz., Escherichia coli, Salmonella, Lactobacillus and Clostridium perfringensas per standard protocols. On $21^{\text {st }}$ and $42^{\text {nd }}$ day of the experiment, from the sacrificed birds, tissue samples of duodenum, jejunum and ileum were collected, flushed with buffered saline and fixed in 10\% neutral buffered formalin for histomorphological studies viz., villus height, crypt depth and goblet cells count.

\section{Statistical analysis}

Experimental data was analysed using SPSS statistical software (Version 20 for windows, SPSS). One-way analysis of variance (ANOVA) was used to analyse variance. Values were expressed as mean \pm SE and compared by Duncan's test. Significance of difference between treatments means was determined at the $\mathrm{P} \leq 0.05$ levels. 


\section{Results and Discussion}

\section{Effect of butyric acid on gut health}

\section{Gut pH}

The effect of dietary butyric acid on gut $\mathrm{pH}$ viz; Duodenum, jejunum and ileum in broiler chicken on day 21 and 42 of the trail is presented in Table 2. On day 21, the duodenal $\mathrm{pH}$ was significantly higher at 0.1 and $0.2 \%$ butyric acid supplementation compared to the control. The jejunal $\mathrm{pH}$ was unaffected. The ileal $\mathrm{pH}$ was significantly higher in $0.4 \%$ butyric acid supplemented group than the groups supplemented with control and $0.1 \%$ BA. On day 42 , the duodenal $\mathrm{pH}$ was significantly higher at $0.4 \%$ butyric acid supplementation compared to the control group. However, the $\mathrm{pH}$ of jejunum and ileum was not affected by different levels of butyric acid supplementation compared to the control group. According to Bolton and Dewar (1965), the free butyrate is absorbed quickly by dissociation and absorption occurs in the upper digestive tract (crop, proventriculus) itself and only less than one per cent is recovered from the upper small intestine. Hence, in the present study the butyric acid might not have lowered the $\mathrm{pH}$ in small intestine and the increase in $\mathrm{pH}$ in few portions observed was within normal physiological range

\section{Caecal microbial count}

The effects of butyric acid supplementation on caecal microbial count of broiler chicken on day 21 and 42 of the experiment are presented in Table 3 and Fig. 1. On day 21, The Escherichia coli count was higher in all BA supplemented groups than that in the control group. There was no significant $(\mathrm{P}>$ 0.05) difference in Salmonella count among different groups. The Clostridium perfringens count was significantly $(\mathrm{P} \leq 0.05)$ higher in
$0.1 \%$ BA group when compared to other groups. The statistical analysis indicated significantly $(\mathrm{P} \leq 0.05)$ lower Lactobacillus count in control group than other groups. On day 42 , non-significant $(\mathrm{P}>0.05)$ difference in Escherichia coli count was recorded between different experimental groups. The Salmonella count was significantly $(\mathrm{P} \leq 0.05)$ higher in control group compared to BA groups. There was significant $(\mathrm{P} \leq 0.05)$ difference in Clostridium perfringens count among different groups. The lowest count was noticed in $0.4 \%$ BA compared to other groups. Statistical analysis indicated significantly $(\mathrm{P} \leq 0.05)$ higher Lactobacillus count in $0.4 \%$ BA group compared to other groups.Vogt et al., (1982) concluded that Sodium butyrate lowers the $\mathrm{pH}$ of intestine that favors the growth of lactic acid producing bacteria such as Lactobacilli spp. as they require an acidic medium for their growth. It has been reported that lactic acid producing bacteria compete for space and nutrients with pathogenic bacteria within the intestine (Furuse and Okumura, 1994; Rolfe, 2000). Lactobacilli spp. produces bacteriocins (Joerger, 2003) which moderate the pathogenic bacterial count and maintain a healthy environment in the bird's intestine. Audisio et al., (2000) reported that sodium butyrate favors the growth of Lactobacilli spp. that converts glucose to lactic acid within the intestine of birds, causing the inhibition of pathogenic bacteria such as Salmonella spp. and E.coli. Collibacillosis is very common in poultry and may be responsible for high chick mortality (Calnek et al., 1991). Kwon and Ricke (2005) showed that butyrate has highest bactericidal efficacy against $E$. coli and Salmonella.

\section{Gut histomorphology}

The effect of butyric acid supplementation on intestinal histomorphologic indices of broilers on day 21 are presented in Table 4. Villous 
height of duodenum and jejunum was significantly higher in $0.4 \%$ and $0.2 \%$ butyric acid supplemented groups, respectively. Jejunal villous height was not affected by butyric acid supplementation Fig.2. Crypt depth of duodenum, jejunum and ileum was significantly higher in $0.1 \%$ butyric acid supplemented group. More number of goblet cells was evident in BA supplemented groups than the control group. The goblet cells in jejunum were unaffected. However, the control group showed more goblet cells compared to butyric acid supplemented groups.

The effect of butyric acid supplementation on intestinal histomorphologic indices of broilers on day 42 are presented in Table 5. Villous height and crypt depth of duodenum and jejunum was significantly higher in $0.2 \%$ butyric acid supplemented group compared to other groups Figure 2 and 3 . Villous height of ileum was significantly higher in $0.1 \%$ butyric acid supplemented group compared to other groups, but crypt depth was unaffected. More number of goblet cells was evident in duodenum in all groups except at $0.4 \% \mathrm{BA}$ supplemented group, whereas jejunum and ileum showed more goblet cells in $0.2 \%$ butyric acid supplemented group, indicating better health of the gut Figure 4. The histomorphometric parameters such as villous height and crypt depth plays a vital role in maintaining gut health and integrity as it is frequently exposed to both nutritional and pathological stress.

Table.1 Per cent ingredient and nutrient composition of basal experimental diet

\begin{tabular}{|c|c|c|c|}
\hline Ingredients & Prestarter (1-7 days) & Starter (8-21 days) & Finisher (22-42 days) \\
\hline Yellow maize & 52.17 & 56.47 & 58.90 \\
\hline Soya bean meal & 40.9 & 35.54 & 32 \\
\hline Vegetable oil & 3.00 & 4.3 & 4.3 \\
\hline Dicalcium phosphate & 1.50 & 1.00 & 0.70 \\
\hline Common salt & 0.40 & 0.35 & 0.35 \\
\hline Mineral mixture* & 1.50 & 1.90 & 1.90 \\
\hline Vitamin premix $* *$ & 0.20 & 0.10 & 0.10 \\
\hline DL-Methionine & 0.20 & 0.15 & 0.15 \\
\hline Vit.B complex with $\mathrm{E}^{* * * *}$ & 0.05 & 0.10 & 0.10 \\
\hline Antibiotic & 0.03 & 0.03 & 0.0 \\
\hline Coccidiostat & 0.05 & 0.05 & 0.0 \\
\hline \multicolumn{4}{|l|}{ Nutrient composition } \\
\hline Crude Protein (\%) ${ }^{b}$ & 22.63 & 18.92 & 20.45 \\
\hline Crude Fat (\%) ${ }^{b}$ & 1.47 & 4.23 & 4.95 \\
\hline Crude Fibre (\%) & 3.39 & 3.51 & 3.73 \\
\hline Moisture (\%) ${ }^{b}$ & 13.29 & 10.81 & 10.07 \\
\hline $\operatorname{Ash}(\%)^{b}$ & 6.86 & 6.54 & 6.23 \\
\hline Calcium $(\%)^{a}$ & 1.03 & 1.01 & 0.97 \\
\hline Phosphorous (\%) ${ }^{a}$ & 0.457 & 0.453 & 0.424 \\
\hline
\end{tabular}

* Mineral mixture: Each 100 g contains Calcium- $30 \%$, Phosphorus- $9 \%$, Manganese- $0.4 \%$, Zinc-0.4 \%, Iron- 2000 ppm, Copper- 500 ppm, Iodine- 100 ppm and Selenium- 23 ppm.

** Vitamin premix: Each gram contains Vitamin A - 82, 500 IU, Vitamin $B_{2}-50 \mathrm{mg}$, Vitamin $\mathrm{D}_{3}-12,000 \mathrm{IU}$ and Vitamin $\mathrm{K}-10 \mathrm{mg}$.

*** Vit. B complex with E: Each gram contains Vitamin $\mathrm{B}_{1^{-}} 4 \mathrm{mg}$, Vitamin $\mathrm{B}_{6^{-}} 8 \mathrm{mg}$, Vitamin $\mathrm{B}_{12}-40 \mathrm{mcg}$, Vitamin E- 40 $\mathrm{mg}$, Calcium D pantothenate- $40 \mathrm{mg}$ and Niacin- $60 \mathrm{mg}$.

${ }^{\mathrm{a}}$ calculated values; ${ }^{\mathrm{b}}$ analyzed value 
Table.2 Effect of butyric acid on Gut $\mathrm{pH}$ in broiler chicken

\begin{tabular}{|c|c|c|c|c|c|c|}
\hline \multirow[t]{2}{*}{ Treatment Groups } & \multicolumn{3}{|c|}{ Gut pH on $21^{\text {st }}$ Day } & \multicolumn{3}{|c|}{ Gut pH on $42^{\text {nd }}$ Day } \\
\hline & Duodenum & Jejunum & Ileum & Duodenum & Jejunum & Ileum \\
\hline Basal diet (Control) & $5.93 \pm 0.01^{b}$ & $6.23 \pm 0.08$ & $6.65 \pm 0.18^{b}$ & $5.73 \pm 0.04^{b}$ & $5.61 \pm 0.08$ & $5.71 \pm 0.16$ \\
\hline $\begin{array}{c}\text { Basal diet }+0.1 \% \\
\text { butyric acid }\end{array}$ & $5.99 \pm 0.02^{\mathrm{a}}$ & $6.46 \pm 0.16$ & $6.49 \pm 0.16^{b}$ & $5.77 \pm 0.03^{a b}$ & $5.71 \pm 0.06$ & $5.99 \pm 0.18$ \\
\hline $\begin{array}{c}\text { Basal diet }+0.2 \% \\
\text { butyric acid }\end{array}$ & $6.01 \pm 0.02^{a}$ & $6.19 \pm 0.14$ & $6.74 \pm 0.13^{\mathrm{ab}}$ & $5.76 \pm 0.03^{a b}$ & $5.62 \pm 0.10$ & $6.16 \pm 0.29$ \\
\hline $\begin{array}{c}\text { Basal diet + } 0.4 \% \\
\text { butyric acid }\end{array}$ & $5.97 \pm 0.01^{a b}$ & $6.38 \pm 0.06$ & $7.21 \pm 0.21^{\mathrm{a}}$ & $5.87 \pm 0.02^{a}$ & $5.66 \pm 0.07$ & $6.24 \pm 0.29$ \\
\hline P value & 0.054 & 0.359 & 0.038 & 0.068 & 0.803 & 0.441 \\
\hline
\end{tabular}

*Values are means \pm standard error. Means within each column with different superscript differ significantly $(\mathrm{P} \leq 0.05)$

Table.3 Effect of butyric acid on Caecal microbial count (CFU/g) in broiler chicken

\begin{tabular}{|c|c|c|c|c|c|}
\hline \multirow[t]{2}{*}{ Treatment Groups } & \multicolumn{5}{|c|}{ Caecal Micro-flora Count $\left(\log _{10}\right.$ CFU/g) on day 21} \\
\hline & Escherichia coli & Salmonella spp. & Clostridium perfringenes & Lactobacillus spp. & P value \\
\hline Basal diet (Control) & $8.65 \pm 0.17^{c}$ & $8.92 \pm 0.15$ & $5.49 \pm 0.26^{b}$ & $8.79 \pm 0.13^{c}$ & 0.000 \\
\hline $\begin{array}{c}\text { Basal diet }+0.1 \% \\
\text { butyric acid }\end{array}$ & $9.19 \pm 0.16^{b}$ & $9.19 \pm 0.17$ & $6.58 \pm 0.30^{a}$ & $9.56 \pm 0.13^{\mathrm{a}}$ & 0.126 \\
\hline $\begin{array}{c}\text { Basal diet }+0.2 \% \\
\text { butyric acid }\end{array}$ & $9.21 \pm 0.05^{b}$ & $8.84 \pm 0.10$ & $5.79 \pm 0.06^{b}$ & $9.18 \pm 0.10^{b}$ & 0.010 \\
\hline $\begin{array}{c}\text { Basal diet }+0.4 \% \\
\text { butyric acid }\end{array}$ & $9.92 \pm 0.01^{\mathrm{a}}$ & $9.25 \pm 0.11$ & $5.93 \pm 0.17^{b}$ & $9.59 \pm 0.09^{\mathrm{a}}$ & 0.000 \\
\hline \multirow[t]{2}{*}{ Treatment Groups } & \multicolumn{5}{|c|}{ Caecal Micro-flora Count $\left(\log _{10}\right.$ CFU/g) on day 42} \\
\hline & Escherichia coli & Salmonella spp. & Clostridium perfringenes & Lactobacillus spp. & P value \\
\hline Basal diet (Control) & $7.16 \pm 0.13$ & $7.35 \pm 0.13^{\mathrm{a}}$ & $7.50 \pm 0.03^{a}$ & $8.05 \pm 0.22^{b}$ & 0.629 \\
\hline $\begin{array}{c}\text { Basal diet }+0.1 \% \\
\text { butyric acid }\end{array}$ & $6.86 \pm 0.21$ & $6.77 \pm 0.15^{b}$ & $6.56 \pm 0.10^{b}$ & $7.96 \pm 0.15^{b}$ & 0.025 \\
\hline $\begin{array}{c}\text { Basal diet }+0.2 \% \\
\text { butyric acid }\end{array}$ & $7.07 \pm 0.26$ & $6.99 \pm 0.11^{\mathrm{ab}}$ & $6.46 \pm 0.03^{b}$ & $7.88 \pm 0.09^{b}$ & 0.000 \\
\hline $\begin{array}{c}\text { Basal diet }+0.4 \% \\
\text { butyric acid }\end{array}$ & $6.86 \pm 0.14$ & $6.85 \pm 0.14^{b}$ & $5.96 \pm 0.09^{c}$ & $9.04 \pm 0.21^{a}$ & 0.000 \\
\hline
\end{tabular}

*Values are means \pm standard error. Means within each column with different superscript differ significantly $(\mathrm{P} \leq 0.05)$ 
Table.4 Effect of butyric acid on Gut histomorphology on $21^{\text {st }}$ day in broiler chicken

\begin{tabular}{|c|c|c|c|c|c|c|}
\hline \multirow[t]{2}{*}{ Parameter } & \multirow[t]{2}{*}{ Site } & \multicolumn{4}{|c|}{ Treatment Groups } & \multirow[t]{2}{*}{$P$ value } \\
\hline & & $\begin{array}{l}\text { Basal diet } \\
\text { (Control) }\end{array}$ & $\begin{array}{c}\text { Basal diet }+0.1 \% \\
\text { butyric acid }\end{array}$ & $\begin{array}{c}\text { Basal diet }+0.2 \% \\
\text { butyric acid }\end{array}$ & $\begin{array}{c}\text { Basal diet }+0.4 \% \\
\text { butyric acid }\end{array}$ & \\
\hline \multirow[t]{3}{*}{ Villous height } & Duodenum & $1550.00 \pm 38.04^{c}$ & $1705.00 \pm 17.78^{b}$ & $1774.16 \pm 41.93^{b}$ & $2090.41 \pm 26.11^{\mathrm{a}}$ & 0.000 \\
\hline & Jejunum & $1095.00 \pm 111.22^{b}$ & $1655.00 \pm 50.16^{a}$ & $1627.91 \pm 86.42^{a}$ & $1259.16 \pm 141.83^{b}$ & 0.000 \\
\hline & ileum & $646.66 \pm 28.47$ & $694.16 \pm 45.10$ & $646.66 \pm 43.98$ & $601.25 \pm 16.76$ & 0.344 \\
\hline \multirow[t]{3}{*}{ Crypt depth } & Duodenum & $191.25 \pm 5.64^{\mathrm{a}}$ & $191.25 \pm 8.59^{\mathrm{a}}$ & $122.08 \pm 6.46^{c}$ & $152.91 \pm 9.01^{b}$ & 0.000 \\
\hline & Jejunum & $141.66 \pm 8.03^{b}$ & $181.66 \pm 9.25^{\mathrm{a}}$ & $108.33 \pm 3.03^{c}$ & $121.66 \pm 4.18^{c}$ & 0.000 \\
\hline & ileum & $117.50 \pm 6.44^{\mathrm{a}}$ & $111.25 \pm 5.00^{\mathrm{a}}$ & $85.41 \pm 3.34^{b}$ & $81.25 \pm 2.59^{b}$ & 0.000 \\
\hline \multirow[t]{3}{*}{ Goblet cell count } & Duodenum & $4.41 \pm 0.33^{b}$ & $8.33 \pm 0.81^{a}$ & $8.58 \pm 0.63^{a}$ & $7.91 \pm 0.55^{\mathrm{a}}$ & 0.000 \\
\hline & Jejunum & $7.00 \pm 0.77$ & $7.91 \pm 1.22$ & $8.33 \pm 0.86$ & $6.75 \pm 0.49$ & 0.544 \\
\hline & ileum & $7.66 \pm 0.87^{\mathrm{a}}$ & $4.66 \pm 0.33^{b c}$ & $3.50 \pm 0.41^{c}$ & $5.75 \pm 0.46^{b}$ & 0.000 \\
\hline
\end{tabular}

$*$ Values are means \pm standard error. Means within each column with different superscript differ significantly $(\mathrm{P} \leq 0.05)$

Table.5 Effect of butyric acid on gut histomorphology on $42^{\text {nd }}$ day in broiler chicken

\begin{tabular}{|c|c|c|c|c|c|c|}
\hline \multirow[t]{2}{*}{ Parameter } & \multirow[t]{2}{*}{ Site } & \multicolumn{4}{|c|}{ Treatment Groups } & \multirow[t]{2}{*}{$P$ value } \\
\hline & & $\begin{array}{l}\text { Basal diet } \\
\text { (Control) }\end{array}$ & $\begin{array}{c}\text { Basal diet }+0.1 \% \\
\text { butyric acid }\end{array}$ & $\begin{array}{c}\text { Basal diet }+0.2 \% \\
\text { butyric acid }\end{array}$ & $\begin{array}{c}\text { Basal diet }+0.4 \% \\
\text { butyric acid }\end{array}$ & \\
\hline \multirow[t]{3}{*}{ Villous height } & Duodenum & $1875.00 \pm 22.35^{b}$ & $2042.50 \pm 93.74^{b}$ & $2254.58 \pm 51.05^{\mathrm{a}}$ & $1889.16 \pm 36.98^{b}$ & 0.000 \\
\hline & Jejunum & $886.25 \pm 39.90^{c}$ & $1437.50 \pm 26.36^{\mathrm{ab}}$ & $1565.00 \pm 41.85^{\mathrm{a}}$ & $1422.08 \pm 70.93^{b}$ & 0.000 \\
\hline & ileum & $729.16 \pm 15.28^{c}$ & $1042.08 \pm 46.46^{\mathrm{a}}$ & $991.66 \pm 26.54^{\mathrm{ab}}$ & $936.66 \pm 15.63^{b}$ & 0.000 \\
\hline \multirow[t]{3}{*}{ Crypt depth } & Duodenum & $302.08 \pm 12.46^{\mathrm{ab}}$ & $293.75 \pm 13.04^{\mathrm{ab}}$ & $325.00 \pm 17.07^{\mathrm{a}}$ & $277.91 \pm 12.40^{b}$ & 0.128 \\
\hline & Jejunum & $223.75 \pm 12.50^{b}$ & $241.25 \pm 15.03^{a b}$ & $280.41 \pm 20.20^{a}$ & $238.33 \pm 8.71^{b}$ & 0.057 \\
\hline & ileum & $182.50 \pm 4.41$ & $202.08 \pm 9.52$ & $185.00 \pm 10.20$ & $204.16 \pm 9.80$ & 0.195 \\
\hline \multirow[t]{3}{*}{ Goblet cell count } & Duodenum & $13.41 \pm 1.45^{\mathrm{a}}$ & $13.66 \pm 0.64^{\mathrm{a}}$ & $11.75 \pm 0.78^{a}$ & $8.16 \pm 0.82^{b}$ & 0.001 \\
\hline & Jejunum & $6.58 \pm 0.46^{b}$ & $7.66 \pm 0.73^{\mathrm{ab}}$ & $8.83 \pm 0.64^{a}$ & $7.83 \pm 0.42^{a b}$ & 0.071 \\
\hline & ileum & $7.58 \pm 0.65^{b}$ & $8.83 \pm 0.62^{b}$ & $11.08 \pm 0.93^{a}$ & $8.16 \pm 0.54^{b}$ & 0.006 \\
\hline
\end{tabular}

*Values are means \pm standard error. Means within each column with different superscript differ significantly $(\mathrm{P} \leq 0.05)$ 
Fig.1 Effect of butyric acid on caecalmicroflorain broiler chicken

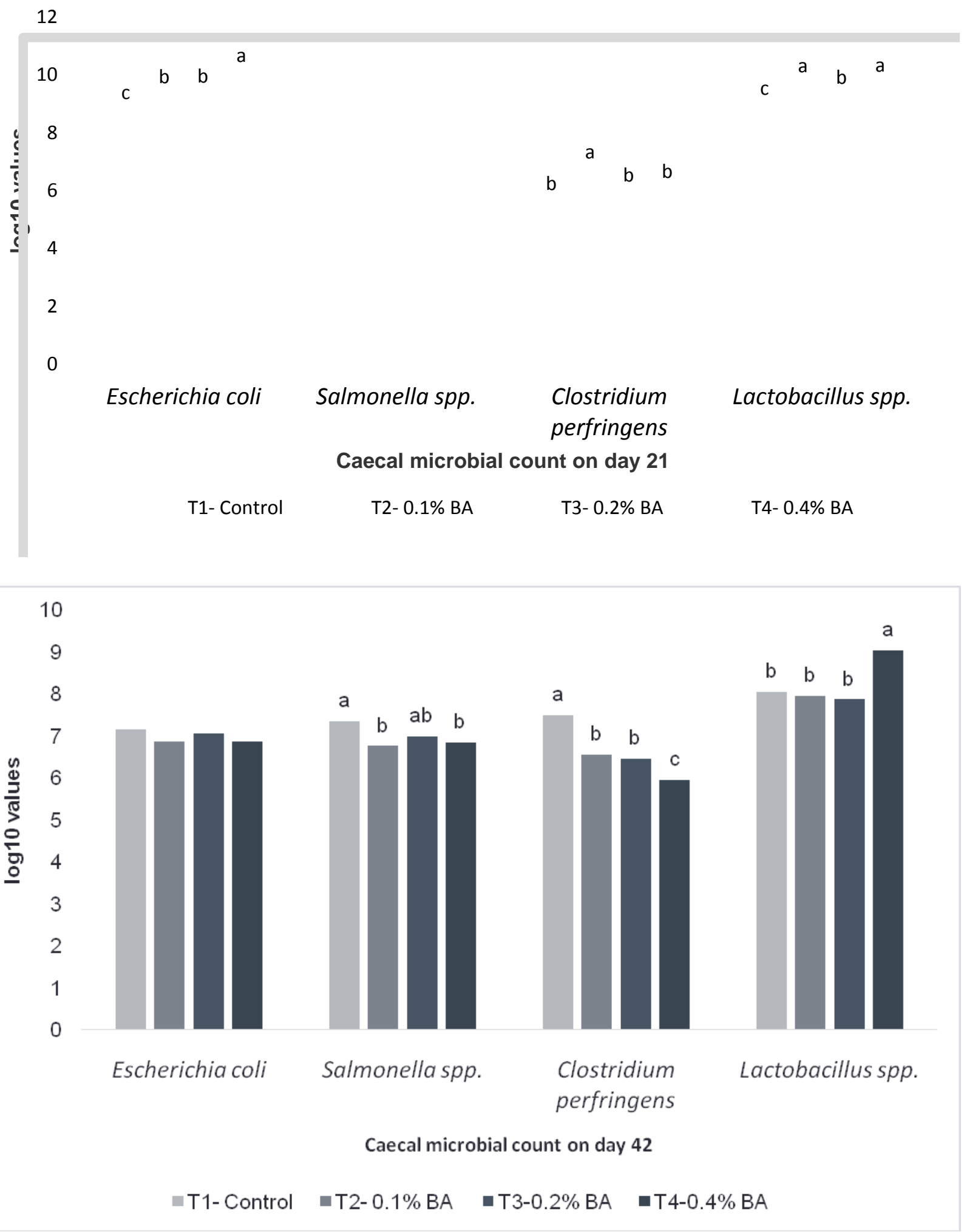


Fig.2 Effect of butyric acid on intestinal villous height in broiler chicken

\section{Villous height on day 42}

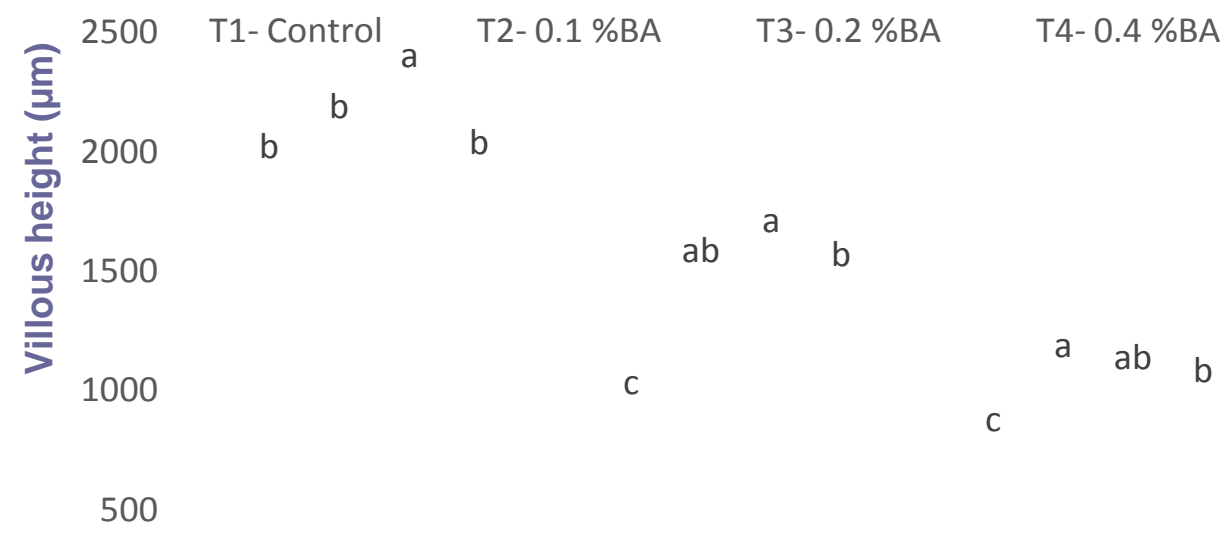

Villous height on day 42

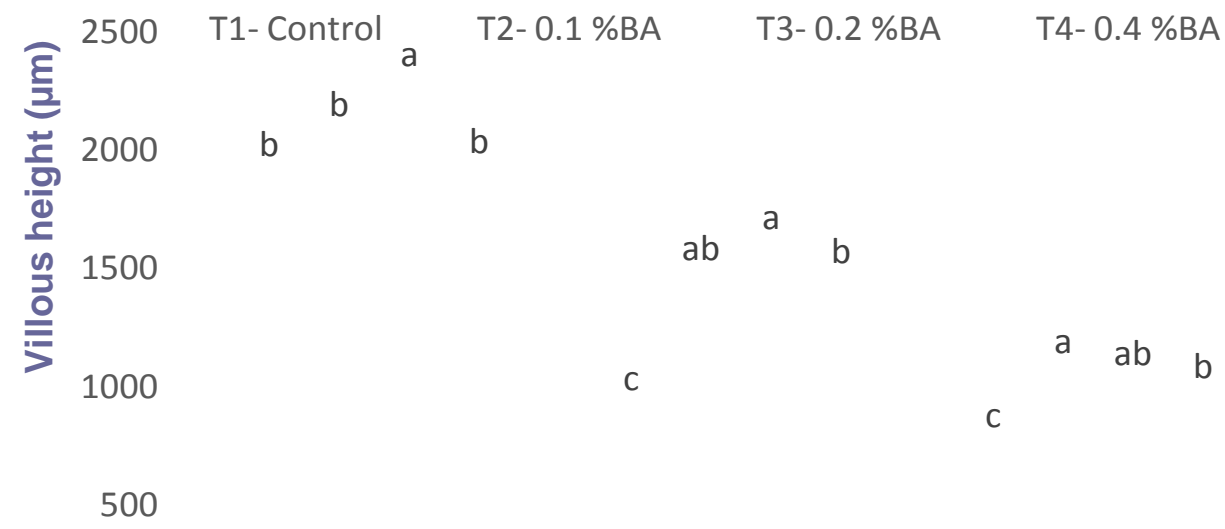

Duodenum Jejunum Ileum 
Fig.3 Effect of butyric acid on intestinal crypt depth in broiler chicken

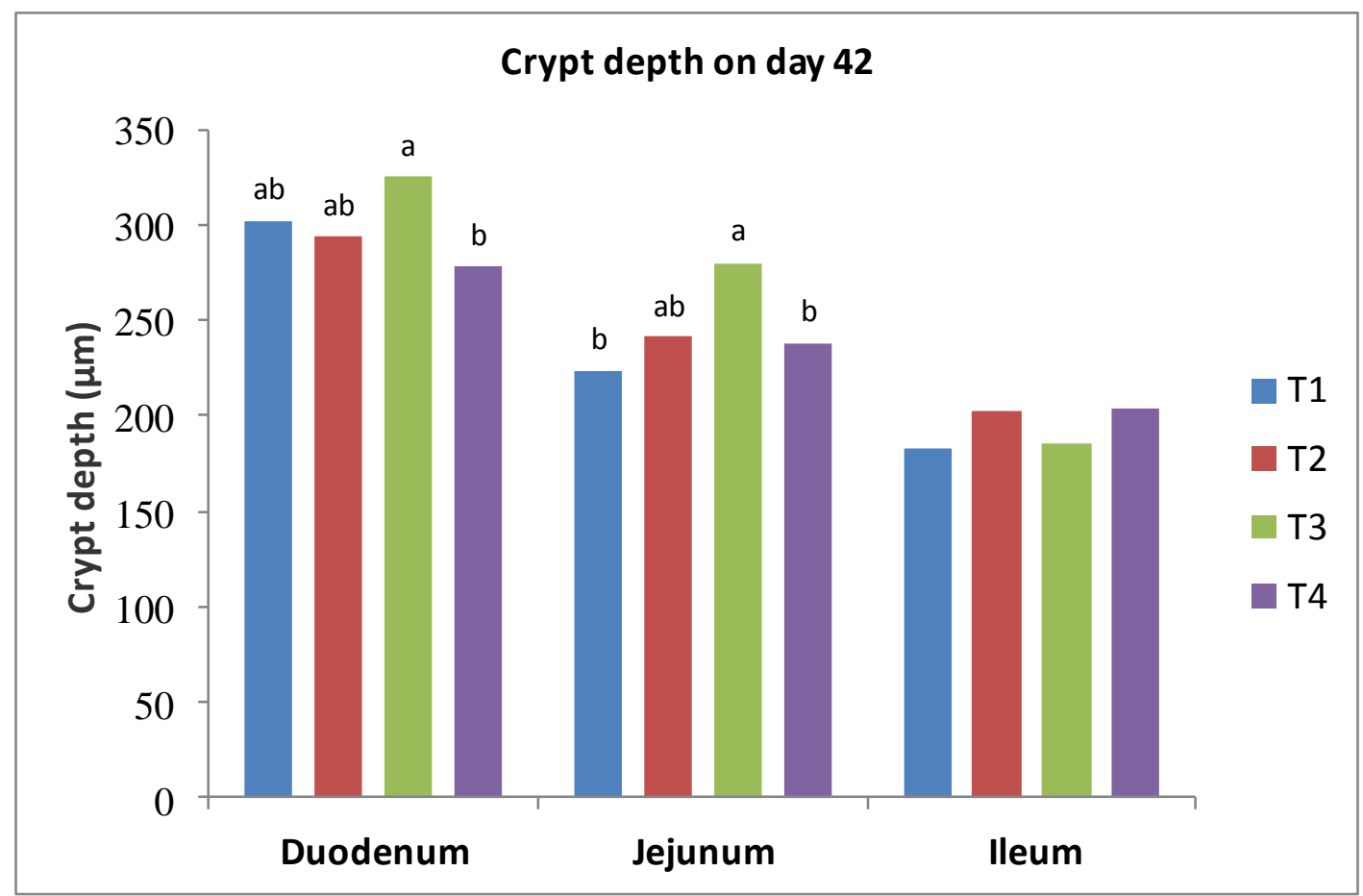

Fig.4 Effect of butyric acid on goblet cell number in broiler chicken

16

14 a a

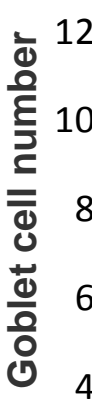

2

0 a

b

Duodenum
Jejunum

Ileum 
The butyric acid appeared to have a role in intestinal development in this study. Small intestine is the site for the absorption of nutrients through epithelial cells which has specialized structures for uptake of nutrients in the gut and subsequently drained into blood stream. The increased villous height and corresponding surface area could support better nutrient uptake and in turn the gain in body weight (Ashraf et al., 2013). The deeper crypt depth indicates increased proliferation of epithelial cells in crypts which repairs the gut epithelial lining for better absorption of nutrients. Butyrate acts as a rich source of energy for enterocytes (Ahsan et al., 2016) and it may possibly increase the cell mitosis in crypts. Sakata (1987) infused butyrate into fistulated rats and found increase in the proliferation of crypt cells in both small and large intestines. Gut health can also be evaluated by determining the number of goblet cells in the epithelial lining of small intestine. The increase in the goblet cell count in the present study is indicative of better protection from the pathogenic and nutritional insult to the small intestine, indicating better gut health. The mucous in the goblet cells acts as lubricant, source of nutrients for the normal commensals and protection of the gut from pathogens (Majidi-Mosieh et al., 2017).

From the results of the present study, it can be concluded that the Gut health in broiler chicken could be improved by supplementation of butyric acid as evidenced by reduced ceacal pathogenic microbial load and increased intestinal morphometrics.

\section{References}

Adil, S., Banday, T., Bhat, G.A., Salahuddin, M., Ahmad Raquib, M. T. and Shanaz, S. 2011. Response of broiler chicken to dietary supplementation of organic acids. J. Central Eur. Agric., 12: 498508.
Ahsan, U., Cengiz, Ö.,Raza, I., Kuter, E., Chacher, M.F.A., Iqbal, Z., Umar, S. and Cakir, S. 2016. Sodium butyrate in chicken nutrition: the dynamics of performance, gut microbiota, gut morphology, and immunity. World's Poult. Sci. J. 72(2): 265-275.

Antongiovanni, M., Buccioni, A., Petacchi, F., Leeson, S., Minieri, S., Martini, A. and Cecchi, R. 2007. Butyric acid glycerides in the diet of broiler chickens: effects on gut histology and carcass composition. Ital. J. Anim. Sci. 6:19-25.

Ashraf, S., Zaneb, H., Yousaf, M.S., Ijaz, A., Sohail, M.U., Muti, S., Usman, M.M., Ijaz, S. and Rehman, H. 2013. Effect of dietary supplementation of prebiotics and probiotics on intestinal microarchitecture in broilers reared under cyclic heat stress. $J$ AnimphysiolAnimNutr97(1):68-73.

Audisio, M.C., Oliver, G. and Apella, M.C. 2000. Protective effect of Enterococcus faecium J96, a potential probiotic strain, on chicks infected with Salmonella pullorum. J. Food Protection 63(10): 1333-1337.

Bolton, W. and Dewar, W.A. 1965. The digestibility of acetic, propionic and butyric acids by the fowl. Br. Poult. Sci. 6(2):103-105.

Calnek, B. W., Barnes, H. J., Beard, C. W., Reid W. M. and Yoder, Jr. H. W. 1991. Diseases of Poultry, 9th edn. (Ames, Iowa State University Press).

Czerwiński, J., Højberg, O., Smulikowska, S., Engberg, R.M. and Mieczkowska, A. 2012. Effects of sodium butyrate and salinomycin upon intestinal microbiota, mucosal morphology and performance of broiler chickens. Arch. Anim.nutr.66(2):102-116.

Dibner, J.J. and Richards, J.D. 2005. Antibiotic growth promoters in agriculture: history and mode of 
action. Poult. sci. 84(4):634-643.

Fern’Andez-Rubio, C., Ord'Onez, C., AbadGonz'Alez, J., Garcia-Gallego, A., Honrubia, M. P., Mallo, J. J. and Bala na-Fouce, R. 2009. Butyric acidbased additives help protect broiler chickens from Salmonella enteritidis infection. Poult. Sci. 88(5):943-948.

Furuse, M. and Okumura, J. 1994. Nutritional and physiological characteristics in germ-free chickens. Comparative Biochemistry and Physiology Part A: Physiol. 109(3): 547-556.

Gunal, M., Yayli, G., Kaya, O., Karahan, N. and Sulak, O. 2006. The effects of antibiotic growth promoter, probiotic or organic acid supplementation on performance, intestinal microflora and tissue of broilers. Int. J. Poult. Sci, 5(2):149-155.

$\mathrm{Hu}$, Z. and Guo, Y. 2007. Effects of dietary sodium butyrate supplementation on the intestinal morphological structure, absorptive function and gut flora in chickens. Anim. Feed Sci. Technol.132(3-4): 240-249.

Joerger, R.D. 2003. Alternatives to antibiotics: bacteriocins, antimicrobial peptides and bacteriophages. Poult. Sci. 82(4): 640-647.

Kwan, Y. M. and Ricke, S. C. 2005. Induction of acid resistance of salmonella typhimurium by exposure to short chain fatty acids. Appl. Environ. Microbiol. 64(9): 3458-3463.

Langhout, D.J., Schutte, J.B., Van Leeuwen, P., Wiebenga, J. and Tamminga, S. 1999. Effect of dietary high-and lowmethylated citrus pectin on the activity of the ilealmicroflora and morphology of the small intestinal wall of broiler chicks. Br. Poult. Sci. 40(3):340-347.

Leeson, S., Namkung, H., Antongiovanni, M. and Lee, E.H. 2005. Effect of butric acid on the performance and carcass yield of broiler chickens. Poult. Sci.
84(9): 1418-1422.

Lesson, S. 2007. Butyratelancing science versus societal issues in poultry nutrition. Nutr. Abstr. Rev. (B). 71:15.

Majidi-Mosleh, A., Sadeghi, A.A., Mousavi, S.N., Chamani, M. and Zarei, A. 2017. Influence of in ovo inoculation of probiotic strains on the jejunal goblet cell counts and morphometry in periand post-hatching chicks. KafkasUniv Vet FakDerg, 23(23):169-72.

Namkung, H., Yu, H., Gong, J. and Leeson, S. 2011. Antimicrobial activity of butyrate glycerides toward Salmonella typhimurium and Clostridium perfringens. Poult. sci. 90(10):22172222.

NRC, 1994. Nutrient Requirements of Poultry. 9th rev. Edn. National Academy Press, Washington.

Naveenkumar, S., Karthikeyan, N., NarendraBabu, R., Veeramani, P., SivaramaKrishnani, S. and Srinivasan, G. 2018. Effect of calcium propionate and coated sodium butyrate as an alternative to antibiotic growth promoters on the serum profile of commercial broiler chicken. Int. J. Chem. Studies 6(1): 36-39.

Ricke, S.C. 2003. Perspectives on the use of organic acids and short chain fatty acids as antimicrobials. Poult. sci. 82(4):632-639.

Rolfe, R.D. 2000. The role of probiotic cultures in the control of gastrointestinal health. The J. Nutri. 130(2): 396-402.

Sakata, T. 1987. Stimulatory effect of shortchain fatty acids on epithelial cell proliferation in the rat intestine: A possible explanation for trophic effects of fermentable fibre, gut microbes and luminal trophic factors. Br. J. Nutr. 58(1):95-103.

Smulikowska, S., Czerwiński, J., 
Mieczkowska, A. and Jankowiak, J. 2009. The effect of fat-coated organic acid salts and a feed enzyme on growth performance, nutrient utilization, microflora activity, and morphology of the small intestine in broiler chickens. J. Anim. and Feed Sci. 18(3): 478-489.

Vogt, H., Matthes, S. and Harnisch, S. 1982.
The effect of organic acids on productivity of broilers. Archives für Geflügelkunde 46: 223-227.

Zhang, W.H., Jiang, Y., Zhu, Q.F., Gao, F., Dai, S.F., Chen, J. and Zhou, G.H. 2011. Sodium butyrate maintains growth performance by regulating the immune response in broiler chickens. Br. poult. Sci. 52(3):292-301.

\section{How to cite this article:}

Nataraja, D., V. Malathi, J. N. Sreedhara, Jayanaik and Kavitha Rani, B. 2020. Effect of Butyric Acid Supplementation on Gut Health in Broiler Chicken. Int.J.Curr.Microbiol.App.Sci. 9(02): 2521-2532. doi: https://doi.org/10.20546/ijcmas.2020.902.287 